\title{
CHALLENGE FOR ANNULMENT
}

\section{DUDAȘ}

\section{Ioana DUDAȘ}

Lecturer PhD.

Faculty of Juridical and Administrative Sciences, Agora University of Oradea, Romania

*Correspondence: Ioana Dudaș, Agora University of Oradea, 8 Piaţa Tineretului St., Oradea, Romania

Email: ioanadudas74@yahoo.com

\section{ABSTRACT:}

The challenge for annulment - an extraordinary legal remedy of withdrawal by which the parties or the prosecutor can obtain the cancellation of a court ruling in the cases exhaustively provided by law. It can be exercised for the purpose of withdrawing court rulings (judgments) that were pronounced in disregard of certain procedural rules, not for reasons of groundlessness. This article aims to highlight the object of the challenge for annulment, the persons who may advance a challenge for annulment, the conditions imposed by the law for the admissibility of such a challenge, and the possible solutions rendered by the court.

KEYWORDS: challenge for annulment, categories of challenges, grounds and conditions of admissibility, court solutions.

\section{INTRODUCTION}

Initially absent from the Civil Procedure Code of year 1865, the challenge for annulment came into being and crystallized in the judicial practice of the time (1865-1948), by using a legal fiction, known as "action for annulment", which was based on the former provisions of Art. 735 of the Civil Procedure Code of 1865. Noting the unequivocal usefulness of the practice in question, the institution of the challenge for annulment "was legally enshrined as an extraordinary legal remedy" through the amendment of the Civil Procedure Code of 1865 by Law no. 18/1948.

The challenge for annulment was defined as "an extraordinary legal remedy of withdrawal, which requires the very court that pronounced the ruling being challenged, in the cases and under the conditions provided by law, to cancel its own ruling and to proceed to a new trial"'.

Some authors have mentioned another feature specific to the institution, namely that it is "non-suspensive of enforcement".

\footnotetext{
${ }^{1} \mathrm{PhD}$ Prof. Ion Deleanu, Tratat de procedură civilă (Civil Procedure Treatise), Servo Sat Publishing House, 2000, p. 440;

${ }^{2}$ Florea Magureanu, Drept Procesual Civil Român (Romanian Civil Procedural Law), All Beck Publishing House, 1998, pp. 436-437;
} 
According to a more recent definition, the challenge for annulment is "an extraordinary, common remedy of withdrawal, whose exercise is aimed at withdrawing (annulling) the ruling being challenged and retrying the case or supplementing the trial"3.

In the context of the entry into force of the new civil procedure code, it was considered that the legal remedy concerned meets the requirements of being "an extraordinary withdrawal remedy, within the reach of the parties to the trial, non-devolutive and nonsuspensive of enforcement, which may be exercised only against final rulings, in the cases and under the conditions provided by law"4.

The new Civil Procedure Code does not bring fundamental novelties in terms of the remedies that can be exercised against court rulings, so that, just like in the Civil Procedure Code of 1865, the appeal, the second appeal, the challenge for annulment, the revision are to be found here, but their purpose (object) is substantially changed, by drawing a clear delineation between extraordinary remedies and appeal. Having been created by the case-law (jurisprudentially) in our procedural law, the challenge for annulment was initially accepted in application of the former provisions of Art. 735 of the Civil Procedure Code of 1865, which made no distinction between procedural documents and court rulings.

In application of Art. 317-321 of the previous Civil Procedure Code, the challenge for annulment was and still is frequently used in practice, especially against the rulings of the courts of second appeal, by invoking procedural irregularities that could hardly be included in the hypotheses of the texts in the matter. The tendency of the subjects addressed by the procedural rule, of turning an extraordinary remedy into one which is open to certain situations that would finally result in the change of the substantive solution, is defeated in the enforcement of the law by a restrictive interpretation of the provisions regulating the extraordinary remedies, which the new Civil Procedure Code has restricted even further, especially in the matter of the (second) appeal.

In the matter of the challenge for annulment, on the basis of the case-law and the doctrine which have noticed the absence, among the hypotheses of the text of Art. 317 of the Civil Procedure Code of 1865, of the one regarding the violation of certain rules of judicial organization, the legislator added this situation as well, but without such extension having any consequences on the extraordinary nature of this remedy. On the contrary, "the clarifications brought in the matter by the terms used determine the restriction of the possibility of exercising this remedy in the already established cases, but the usefulness of the challenge for annulment appears as evident in the context of the pronouncement of certain irrevocable rulings, within the new wording of the code, final rulings, which can no longer be appealed against, and have been pronounced by a court not legally constituted"5.

The usefulness of the challenge for annulment, proved by the very manner in which it is regulated in the new Civil Procedure Code as well, justifies our attempt to analyze it as follows.

\section{OBJECT OF THE CHALLENGE FOR ANNULMENT}

\footnotetext{
${ }^{3}$ Viorel Mihai Ciobanu, Gabriel Boroi, Traian Cornel Briciu, Drept Procesual civil (Civil Procedural Law), C.H.Beck Publishing House, 2011, p. 365;

${ }^{4}$ Viorel Mihai Ciobanu, Gabriel Boroi, Traian Cornel Briciu, Drept Procesual civil (Civil Procedural Law), C.H.Beck Publishing House, 2011, p. 366;

${ }^{5}$ Sebastian Spinei, Reglementarea căilor de atac în dreptul procesual civil (The Regulation of Remedies in Civil Procedural Law), Universul Juridic Publishing House, 2013, p. 140;
} 


\section{CHALLENGE FOR ANNULMENT}

According to Art. 503 par. 1 of the New Civil Procedure Code, "final rulings can be contested through a challenge for annulment when the challenger was not legally summoned and was not present at the time when the trial took place" 6 .

Paragraph 2 of the same Article states that, "The rulings of the courts of second appeal can also be contested through a challenge for annulment in cases where:

1. the ruling rendered in the second appeal was delivered by a court having an absolute lack of jurisdiction, or in violation of the rules regarding the composition of the court and, although the appropriate exception had been invoked, the court of second appeal omitted to rule on that aspect;

2. the solution given to the second appeal is the result of a material error;

3. the court of second appeal, in rejecting the second appeal or admitting it in part, omitted to investigate any of the grounds for quashing (cassation) invoked by the claimant in the second appeal within the time limit set;

4. the court of second appeal did not rule on one of the second appeals filed in the case.

The provisions of par. (2) points 1, 2 and 4 of the New Civil Procedure Code properly apply to the rulings of the courts of appeal which, according to the law, cannot be challenged by second appeal.

Therefore, according to the stated text, the challenges for annulment is classified as an extraordinary legal remedy of withdrawal, which is common and non-suspensive of enforcement.

Under the rule of the previous regulation, the doctrine distinguished between two categories of challenges for annulment, depending on the type of court rulings that were their object: the ordinary, common-law challenge for annulment, and the special challenge for annulment.

This distinction remains relevant in the new Code, the ordinary challenge for annulment being regulated in par. (1) of Art. 503 of the New Civil Procedure Code, and the special one, in the following paragraphs of the same Article.

The object of the challenge for annulment is regulated differently depending on the grounds on the basis of which this extraordinary remedy can be exercised. According to par. (1) of Art. 503, for the grounds related to the irregularity of the summoning procedure, the rulings which are likely to be appealed against through challenge for annulment are all the final rulings (irrevocable rulings, according to the terminology of the Civil Procedure Code of 1865). Final rulings are those defined in Art. 634 of the New Civil Procedure Code and, as the text relied upon shows, these may be judgments rendered in first instance, on appeal or on second appeal, which, for various reasons, cannot be or can no longer be challenged by appeal or second appeal.

Paragraphs (2) and (3) of Art. 503 regulate other reasons on the basis of which the challenge for annulment can be exercised, but these concern only the rulings of the courts of second appeal and the rulings of the courts of appeal which, according to the law, cannot be challenged by second appeal.

In support of the challenge for annulment, only irregularities of a procedural nature can be invoked, such as: the illegal summoning and absence of the party, the lack of

\footnotetext{
${ }^{6}$ Civil Procedure Code - MJR official edition 2015, pp. 195-196
} 
jurisdiction, the illegal composition of the court, the omission to rule on one of the second appeals filed or the omission to investigate any of the grounds for quashing.

Judicial practice has ruled that the challenge for annulment in support of which other reasons than those provided by the procedure code are invoked is not admissible, such reasons being: the lack of legal standing of one of the parties, the omission to summon the party for the hearing to which the pronouncement of the ruling was postponed, the non-observance of the principle of orality of the debates, the serious violation of the right to defense or the court's omission to order, ex officio, the production of evidence.

\section{ORDINARY CHALLENGE FOR ANNULMENT.}

Grounds: illegal summoning. The ordinary challenge for annulment, which can be brought against any final ruling, is limited to a single reason: the challenger was not legally summoned and was not present at the time when the trial took place. Paragraph (1) of Art. 503 of the New Civil Procedure Code takes over the idea of the former Art. 317 par. (1) point 1 of the old Civil Procedure Code of 1865, but resorts to a more rigorous wording, making use of the jurisprudential solutions generated by the imperfections of the former text.

Thus, it is stipulated that the irregularity of the summoning procedure should concern specifically the challenger, not the party in general, which excludes de plano the possibility of a challenge for annulment being filed by a party who invokes the illegal summoning of another party to the trial. The negative condition that the challenger concerned should not have been present at the time when the case was tried must be met cumulatively with the irregularity of the summoning procedure. This rule considers, on the one hand, that the presence of the party at the hearing covers the complete absence of summoning and, on the other hand, that any other flaw of a defective summoning could have been invoked by the party at that time.

In practice it has been decided, for example, that the following are cases of illegal summoning:

- the death of one of the parties was not brought to the attention of the court, with the consequence of the non-summoning of the heirs of the deceased person;

- the non-summoning of the challenging party at its main office, if such an obligation was established by law;

- the summoning of the party by publicity, although the conditions for this have not been fulfilled;

- the failure to comply with the legal requirements regarding the content of the summons.

\section{SPECIAL CHALLENGE FOR ANNULMENT. GROUNDS.}

According to the current regulation, the rulings of the courts of second appeal and those of the courts of appeal not subject to second appeal can be contested through a challenge for annulment on grounds of illegal summoning, as provided by par. (1), and also for a number of other reasons provided expressly and exhaustively, just like in the previous regulation, by the current par. (2) of Art. 503 of the New Civil Procedure Code.

As compared to Art. 318 of the old Civil Procedure Code of 1865, the new text presents as grounds for a special challenge the lack of jurisdiction, and it also adds the reasons that consist in the violation of the rules regarding the composition of the court and the omission to rule on one of the second appeals or appeals filed in the case. 


\section{CHALLENGE FOR ANNULMENT}

\section{LACK OF JURISDICTION}

The reason regarding the lack of jurisdiction, provided in Art. 503, par. (2), point 1 of the New Civil Procedure Code, refers exclusively to the lack of jurisdiction of the court which pronounced the judgment being challenged, namely the court of second appeal or, as the case may be, the court of appeal, under the conditions of par. (3) of the same Article.

Therefore, it is not possible to invoke, by means of a challenge for annulment, reasons regarding a possible lack of jurisdiction of the court that has adjudicated in a previous procedural stage. This new regulation is integrated into the vision of the current code, which has significantly limited the possibility of invoking the exception of lack of jurisdiction at various stages of the civil lawsuit. Also, it should be noted, in the context described above, that the lack of jurisdiction of the court which rendered the judgment being challenged should have been absolute, and the exception of lack of jurisdiction should have been invoked before that court, but the court should have omitted to rule on it. The text does not provide for the circumstance according to which the exception should have been invoked by the challenger himself, so it can be inferred that it is sufficient for it to have been invoked by any disputing party or even ex officio. As for the reason regarding the absolute lack of jurisdiction of the court - a ground for the common-law challenge for annulment in the previous regulation -, in the judicial practice it has been ruled that the challenge for annulment is admissible in the event that the court, by exceeding its jurisdiction, has solved an exception of unconstitutionality.

\section{COMPOSITION OF THE COURT}

The violation of the rules regarding the composition of the court is a new ground for the challenge for annulment and a ground for reconsidering the practice of the law courts in recent years, which, quite rightly, did not assimilate the illegal composition of the court with its lack of jurisdiction. The reason provided by point 1, second thesis of Art. 503, par. (2), is also found as a ground for quashing the ruling in a second appeal, being provided by Art. 488 par. (1) point 1 of the New Civil Procedure Code, but, as we have also shown for the reason regarding the lack of jurisdiction, the illegal composition of the court must concern the very court of second appeal or of appeal that delivered the ruling being challenged, and the exception of illegal composition must have been invoked before that court, which has omitted to rule on it.

\section{MATERIAL ERROR}

The reason according to which the contested judgment must be the result of a material error is taken over from the former regulation of Art. 318 of the Civil Procedure Code of 1865 , the word "mistake" being replaced by its synonym "error".

The case-law generated by the application of that Article has preserved its relevance: this ground for the special challenge for annulment refers to the committing of a material error, in the sense of a mistake of a procedural nature that consists of confusing important elements or material data - such as wrongly rejecting the second appeal as not stamped, as late or as filed by a person without legal standing, resolving the second appeal in the absence of the grounds for second appeal, which were not transmitted by the court whose judgment is challenged, incorrect statements regarding procedural incidents, ruling on a judgment other than the one subject to the second appeal -, for the verification of which it is not necessary to re-examine the merits or to reassess the evidence and which have determined the solution 


\section{Ioana Dudas}

rendered, not errors of judgment, or errors in the assessment of the evidence, in the interpretation and application of the legal provisions. The challenge for annulment cannot be used to censure the material errors that have slipped in the content of the court rulings/judgments, for the rectification of which the legislator has made available the procedure for rectification of judgments regulated by Art. 442 of the New Civil Procedure Code. In order to solve the challenge for annulment on this ground, the court must refer to the situation existing in the file on the date of the judgment being challenged, without analyzing any such grounds that occurred subsequently.

\section{THE OMISSION TO INVESTIGATE A REASON FOR QUASHING}

As regards this reason for the special challenge for annulment, it should be noted first of all that it concerns exclusively the rulings of the courts of second appeal, not those of the courts of appeal which are not subject to second appeal, as expressly provided in par. (3) of Art. 503. We believe that the explanation lies in the fact that only the second appeal can be triggered by reasons for quashing that are expressly and exhaustively provided by law; otherwise, the failure to analyze certain reasons for appeal, within the limits of devolution (transfer of rights), may cause a similar prejudice to the party, given that the possibility of second appeal is not available to it.

Secondly, we note that, unlike the regulation in Art. 318 of the old Civil Procedure Code of 1865, the provisions of Art. 503 par. (2) point 3 of the New Civil Procedure Code no longer expressly stipulate the requirement that the omission to investigate the reason for quashing should have occurred by mistake. We believe that the removal of the phrase "by mistake" does not cause any change in the meaning or purpose of the regulation and that the interpretation given to the former text, according to which the failure to investigate the reason should have been the result of an omission, not deliberate, remains valid.

Thus, under the rule of the former regulation, in practice it was decided that, in cases where the court of second appeal actually analyzed only a reason for quashing which it found to be unfounded and showed, in the reasoning of its solution, why the other reasons could not be analyzed, the failure to analyze all the reasons invoked by the claimant in the second appeal is not due to an omission committed by mistake by the court, but it was of a deliberate nature, and the reasons why the court of second appeal proceeded in this way cannot be censured by means of the challenge for annulment, because such remedy cannot be used as a second appeal against second appeal. In the case-law ${ }^{7}$, it has also been stated that the regulation of this ground of challenge had in view the possibility of censuring the ruling of the court of second appeal exclusively and by limitation to the omitted reason for quashing, otherwise the remedy of a second appeal against second appeal being available. The challenge for annulment based on this reason can be advanced only by the claimant in the second appeal, if the respondent in the second appeal did not prove he had a legitimate and current interest, and the decision rendered in the retrial, following the cancellation of the judgment of the court of second appeal, will be limited, from the standpoint of the analysis, to the reason for quashing whose non-investigation has led to the cancellation. The investigation of the reasons for quashing consists in the analysis of the grounds of second appeal, as stated by the

\footnotetext{
${ }^{7}$ See also the Decision of the Constitutional Court of Romania (CCR) no. 483 of 23 June 2015, published in the Official Journal of Romania, Part I, no. 633 of 20 August 2015, as well as Decision 673/2017, published in the Official Journal of Romania, Part I, no. 92/2018 of 31 January 2018.
} 


\section{CHALLENGE FOR ANNULMENT}

party in the application for second appeal, not of the court's omission to respond to each factual and legal submission invoked by the claimant in the second appeal, as these must be subsumed by one of the grounds of second appeal provided by law.

On the other hand, the investigation to which the legal text makes reference, without being interpreted as imposing on the court the duty to respond to each individual submission, must be an actual examination of the criticism subject to judicial review, not just a repetition of the conclusions of the lower courts, otherwise the guarantees of the right to a fair trial enshrined in Art. 6 par. 1 of the European Convention on Human Rights ${ }^{8}$ might be prejudiced.

The remedy of the challenge for annulment for this reason cannot be used to censure the manner in which the court of second appeal, in analyzing the reason for quashing, responded to it or the court's omission to investigate reasons for quashing that were filed late or which should have been invoked by the court ex officio.

Also, the omission of the court to award the legal fees cannot be subject to censure for this reason, because the entitled party has access to the remedy of an action for the recovery of the legal fees determined by the guilty conduct of the other party, nor can the refusal of the court to grant a hearing for lack of defense be subject to censure. The challenge for annulment may be advanced only in the event that the second appeal has been admitted only in part, not in cases where it has been fully admitted or cancelled as unstamped. On the other hand, if the omission concerns the public order grounds orally invoked by the claimant in the second appeal, or submitted to the parties for discussion by the court ex officio, the challenge for annulment for this reason is admissible.

The corresponding former text, namely Art. 318 of the old Civil Procedure Code of 1865 , has been the subject to a judicial review of constitutionality ${ }^{9}$, the Constitutional Court ruling that the legal provisions governing the special challenge for annulment for the reason consisting in the omission of the court of second appeal to rule on any of the reasons for quashing, do not contravene the Constitution, the principle of the right of the party to a fair trial, or the principle of the authority of res judicata - a principle that has not been enshrined in the Constitution -, since the court vested with the adjudication of the challenge is called

\footnotetext{
${ }^{8}$ See - The Convention for the Protection of Human Rights and Fundamental Freedoms, drawn up within the Council of Europe, opened for signature in Rome, on 4 November 1950, which entered into force in September 1953. According to the intentions of its authors, it is about adopting the first measures meant to ensure the collective guarantee of some of the rights listed in the Universal Declaration of Human Rights of 1948.

The Convention enshrines, on the one hand, a number of civil and political rights and freedoms, and, on the other hand, it establishes a system meant to guarantee them and to ensure the compliance of the contracting states with the obligations assumed by them. By Law no. 30 of 18 May 1994, Romania ratified the European Convention for the Protection of Human Rights (ECHR), as well as its Additional Protocols No. 1, 4, 6, 7, 9, 10. Separately from the enshrinement of the integration of international law into the domestic legal system, the fundamental law of Romania contains specific regulations regarding international treaties on human rights. According to the provisions contained in Art. 11 and 20 of the Constitution, the Convention and its additional protocols have become an integral part of domestic law, taking precedence over it, in other words, ECHR and its additional protocols have become a source of mandatory and primary domestic law, which, at national level, has as an immediate consequence the application of the convention and of its protocols by the Romanian courts, and at the international level, the acceptance of the review provided by the ECHR with regard to domestic court judgments/rulings. As a guarantee of the respect for human rights, the Convention provides, in Art. 6, point 1, the right of any person to a fair trial: "Everyone is entitled to a fair and public hearing within a reasonable time by an independent and impartial tribunal established by law [...]".

${ }^{9}$ See the Decision of the Constitutional Court of Romania no. 1033 of 9 July 2009 regarding the exception of unconstitutionality of the provisions of Art. 318 of the Civil Procedure Code of 1865, published in the Official Journal of Romania, Part I, no. 634/2009 of 25 September 2009.
} 
upon to examine the reasons for quashing that the court of second appeal has omitted to investigate.

\section{THE OMISSION TO RULE ON A SECOND APPEAL/AN APPEAL}

This is a newly introduced reason, provided in point 4, par. (2), Art. 503 of the New Civil Procedure Code, according to the logic that, if in the case of non-investigation of a reason for second appeal, a challenge for annulment can be brought, then, a fortiori, the same remedy should be available in cases where an entire second appeal is omitted.

The same regulation applies in cases where the ruling on one of the appeals filed in the case, according to par. (3) of Art. 503 of the New Civil Procedure Code, is omitted. In order for this reason to apply, instead of the one provided for in point 3 of the aforementioned legal text, the mention regarding the solution given to the remedy concerned (admission, rejection/dismissal, cancellation, obsolescence), must be missing from the operative part of the decision rendered by the court of second appeal or of appeal.

We believe that such absence may be exploited by the remedy of the challenge for annulment, even if in the recitals of the decision there is mention of that second appeal or appeal or of the reasons that would trigger one solution or another with regard to that remedy, because the lack of mention in the operative part is equivalent to the lack of certainty that a deliberation and consensus of the members of the panel of judges with regard to the solution of that legal remedy even took place.

The challenge for annulment is inadmissible if the reason provided in Art. $503^{10}$ par. (1) could have been invoked by way of appeal or second appeal. However, the challenge may

\footnotetext{
${ }^{10}$ See the Decision of the Constitutional Court of Romania no. 828 of 11 December 2018, which was published in the Official Journal of Romania, Part I no. 263 of 05 April 2019 - referring to the rejection of the exception of unconstitutionality of the provisions of Art. 503 par. (2) point 1 of the Civil Procedure Code, according to which: "(2) The rulings of the courts of second appeal can also be contested through a challenge for annulment in cases where: 1. the ruling rendered in the second appeal was delivered by a court having an absolute lack of jurisdiction, or in violation of the rules regarding the composition of the court and, although the appropriate exception had been invoked, the court of second appeal omitted to rule on that aspect;" they were subject to the judicial review of constitutionality, the court holding in its recitals that, as regards the conditions for exercising the remedies, the legislator can regulate the time limits for filing them, the form in which the filing must be done, its content, the court to which it is submitted, the jurisdiction and the method of adjudication, the solutions that can be adopted and other things of the kind, without thereby infringing the law in its substance or the constitutional principles and texts of reference. Thus, the Strasbourg Court, in its Decision of 12 November 2002, rendered in the case of Beles and Others v. the Czech Republic, paragraph 61, found that the right of access to a court is not absolute and is subject to limitations permitted by implication, given that it calls for regulation by the State, which enjoys a certain margin of appreciation in this regard. For these reasons, the criticism regarding the violation of Art. 21 of the Constitution and Art. 6 of the Convention for the Protection of Human Rights and Fundamental Freedoms cannot be retained as valid. Moreover, the criticism of the exception's authors that the legal provisions criticized are unconstitutional, because "the possibility that the party seeking justice can request that the second appeal be adjudicated in absentia, in which case the exception of the lack of public order jurisdiction of the court cannot be invoked, is not taken into account", does not concern constitutionality issues, but the application of the legal provision to their concrete situation in the litigation in which the exception of unconstitutionality was invoked. The fact that a certain procedural provision does not regulate all the hypotheses that may arise in practice does not constitute a violation of the right to a fair trial of the parties, who have the possibility to avail themselves of all its guarantees, by proposing, approving and producing relevant and useful evidence in the case, under the conditions established by the legislator. The Court also holds that, according to Art. 10 and Art. 12 of the Civil Procedure Code, "the parties have the obligation to submit the procedural documents under the conditions, in the order and within the deadlines established by the law or the judge, to prove their claims and defenses, to contribute to the unfolding of the trial without delay, pursuing its completion in the same manner", and "the procedural rights must be exercised in good faith, according to the purpose for which they were recognized by the law and without infringing the procedural rights of another party". At the same time, the provisions of Art. 22 paragraphs (1) and (2) of the Civil Procedure Code
} 


\section{CHALLENGE FOR ANNULMENT}

be accepted if the reason was invoked by the application for second appeal, but the court rejected it because it required factual checks that were incompatible with the second appeal or if the second appeal, without this being the fault of the party, was rejected without being investigated on the merits.

\section{THE COURT HAVING JURISDICTION AND THE TIME LIMIT FOR RESORTING TO LEGAL REMEDIES}

According to Art. 505, par. (1) of the New Civil Procedure Code, the jurisdiction for resolving the challenge for annulment rests with the court which delivered the judgment thus challenged $^{11}$. As a novelty, in par. (2) of Art. 505, the legislator expressly regulates that, in the event that there are reasons invoked which pertain to different jurisdictions, the prorogation of jurisdiction shall not operate.

As regards the time limit for resorting to the legal remedy, Art. 506 of the New Civil Procedure Code maintains the two conditions that have to be fulfilled cumulatively (which were demanded even by the former regulation, in Article 319, par. (2) of the Civil Procedure Code of 1865, namely: (1) the actual time limit for resorting to the legal remedy should not exceed 15 days, calculated from the date of communication of the judgment, and (2) it should not exceed a period of one year, calculated from the date on which the judgment became final.

According to par. (2) of Art. 506 of the New Civil Procedure Code, the grounds on which the challenge is based must be specified within a 15-day time limit, which is a limitation period, prescribed for its filing, under the sanction of nullity. It was held that the New Civil Procedure Code brings novelties in the matter of incompatibility, so that, according to Art. 41 of the New Civil Procedure Code, the judge who delivered a judgment (interlocutory judgment or judgment by which the case was resolved) cannot adjudicate the same case either in the challenge for annulment or in the revision procedure ${ }^{12}$.

\section{CODE) \\ THE TRIAL PROCEDURE (ART. 508 OF THE NEW CIVIL PROCEDURE}

The adjudication of the challenge for annulment is done with urgency and priority, with the application of the procedural stipulations relevant for the trial that led to the judgment being challenged. The statement of defense is compulsory according to the provisions of Art. 508 par. 2 of the Civil Procedure Code, having to be filed at least five days prior to the first court hearing. It is not communicated to the challenger, the latter becoming familiar with its content from the case file. The doctrine has pleaded for the avoidance of a stricto sensu interpretation of the provisions of Art. 508, par. (2) of the New Civil Procedure Code. In this regard, an opinion was expressed that, in order to ensure equal treatment, the

\footnotetext{
enshrine the active role of the judge in solving the case, the latter having the duty to insist, by all legal means, in order to prevent any mistake regarding the finding of the truth in the case.

${ }^{11}$ See Decision no. 1163/2017 - High Court of Cassation and Justice - Civil Division I - published on scj.ro

12 See Decision no. 830/2017 - recusation - High Court of Cassation and Justice (HCCJ) - Civil Division I Published in the HCCJ of 18 May 2017, as well as Decision no. 2/2007 regarding the examination of the second appeal in the interest of the law, filed by the General Prosecutor of the Prosecutor's Office attached to the High Court of Cassation and Justice, on the compatibility of participation in the adjudication of the application (motion) for revision or of the challenge for annulment of the judge who previously solved the case on the merits - High Court of Cassation and Justice - HCCJ - Published by the HCCJ on 15 January 2007- published on scj.ro
} 


\section{Ioana Dudas}

challenger should at least benefit from the permission to obtain, upon request, a copy of the statement of defense ${ }^{13}$.

Art. 508, par. (3) operates a distinction, depending on whether or not it is possible to annul the challenged judgment/ruling and to settle the case within the same hearing: a) Whenever possible, only if the reason for the challenge is well-founded, the court will issue a single judgment, by which it annuls the judgment being challenged and resolves the case; $b$ ) Otherwise, the court pronounces the annulment of the judgment being challenged and sets a hearing in view of resolving the case through the delivery of a new judgment, in which case the annulment judgment cannot be appealed against separately (but only together with the judgment resolving the case $)^{14}$. The last provision was welcomed, as it was pointed out that, under the rule of the Civil Procedure Code of 1865, the doctrine used to express different opinions, regarding the options for solving the situation: either by ordering the admission of the challenge through an interlocutory order, or - according to another opinion - through a judgment of admission in principle, which had to remain irrevocable, as a prerequisite of the judgment on the merits. From the text, it is univocally clear that the annulment of the judgment challenged occurs by effect of a judgment, not of an order. The judgment which resolves the challenge for annulment is likely to be appealed against by using the same remedies that were available for the judgment being challenged. A judgment against which the challenge for annulment was exercised cannot be contested by the same party by means of a new challenge for annulment, even if new reasons are invoked.

In conclusion, we can say that, in New Civil Procedure Code, the extraordinary legal remedy of the challenge for annulment, as currently structured, has put forward the doctrinal and jurisprudential solutions advanced in the last decades. The two forms of the challenge for annulment that have become traditional were merged into a single text. Also, the time limit for exercising the challenge for annulment according to Art. 506 of the Civil Procedure Code was reconsidered, and the distinction between judgments susceptible to be enforced by coercion and those not susceptible to be enforced by coercion was removed. The innovations brought by the New Civil Procedure Code in the matter, which were subject to the above considerations, are interesting, and some are quite original. This is, for example, the case of the provisions regarding the judgments to be pronounced in case of admitting the challenge [Art. 502 par. (2)]. In this study, we have also noted the existence of other procedural stipulations meant to bring important clarifications for the correct application of the legal provisions regarding the challenge for annulment, which we consider to be an extremely useful institution of civil procedural law.

\section{BIBLIOGRAPHY}

PhD Prof. Ion Deleanu, Tratat de procedură civilă (Civil Procedure Treatise), Servo Sat Publishing House, 2000;

Florea Magureanu, Drept Procesual Civil Român (Romanian Civil Procedural Law), All Beck Publishing House, 1998;

\footnotetext{
${ }^{13}$ See Civil Decision no. 303/2016 pronounced by the High Court of Cassation and Justice - Panel of 5 Judges Published by the HCCJ on 31 October 2016- published on scj.ro

${ }^{14}$ Decision no. 2546/2014 on financial rights - High Court of Cassation and Justice - Civil Division I - Published by the HCCJ on 02 October 2014; Decision no. 525/2015 - High Court of Cassation and Justice - Civil Division I, published in the HCCJ of 19 February 2015, respectively Decision no. 706/2015 - High Court of Cassation and Justice - Civil Division II - Published in the HCCJ of 03 March 2015- published on scj.ro
} 


\section{CHALLENGE FOR ANNULMENT}

Viorel Mihai Ciobanu, Gabriel Boroi, Traian Cornel Briciu, Drept Procesual civil (Civil Procedural Law), C.H.Beck Publishing House, 2011;

Sebastian Spinei, Reglementarea căilor de atac în dreptul procesual civil (The Regulation of Remedies in Civil Procedural Law), Universul Juridic Publishing House, 2013;

Civil Procedure Code - MJR official edition 2015;

The Convention for the Protection of Human Rights and Fundamental Freedoms, drawn up within the Council of Europe, opened for signature in Rome, on 4 November 1950, which entered into force in September 1953;

Decision of the Constitutional Court of Romania (CCR) no. 483 of 23 June 2015, published in the Official Journal of Romania, Part I, no. 633 of 20 August 2015, as well as Decision 673/2017, published in the Official Journal of Romania, Part I, no. 92/2018 of 31 January 2018;

Decision of the Constitutional Court of Romania no. 1033 of 9 July 2009 regarding the exception of unconstitutionality of the provisions of Art. 318 of the Civil Procedure Code of 1865, published in the Official Journal of Romania, Part I, no. 634/2009 of 25 September 2009 ;

Decision of the Constitutional Court of Romania no. 828 of 11 December 2018, which was published in the Official Journal of Romania, Part I, no. 263 of 05 April 2019;

Decision no. 1163/2017 - High Court of Cassation and Justice - Civil Division I - published on scj.ro;

Decision no. 830/2017 pronounced by the High Court of Cassation and Justice (HCCJ) - Civil Division I - Published in the HCCJ of 18 May 2017;

Decision no. 2/2007 regarding the examination of the second appeal in the interest of the law, filed by the General Prosecutor of the Prosecutor's Office attached to the High Court of Cassation and Justice, on the compatibility of participation in the adjudication of the application (motion) for revision or of the challenge for annulment of the judge who previously solved the case on the merits - High Court of Cassation and Justice - HCCJ Published by the HCCJ on 15 January 2007- published on scj.ro;

Civil Decision no. 303/2016 pronounced by the High Court of Cassation and Justice - Panel of 5 Judges - Published by the HCCJ on 31 October 2016 - published on scj.ro;

Decision no. 2546/2014 on financial rights - High Court of Cassation and Justice - Civil Division I - Published by the HCCJ on 02 October 2014;

Decision no. 525/2015 - High Court of Cassation and Justice - Civil Division I, published in the HCCJ of 19 February 2015, respectively Decision no. 706/2015 - High Court of Cassation and Justice - Civil Division II - Published in the HCCJ of 03 March 2015- published on scj.ro. 